\title{
The peculiarities of tourism development as a driver of economic development of the region
}

\author{
Tamara Tsatkhlanova ${ }^{1 *}$, Elzata Erdnieva ${ }^{1}$, Bayrta Ubushaeva $^{2}$, Namina Burkutbaeva $^{1}$, and \\ Danara Erendzhenova ${ }^{1}$ \\ ${ }^{1}$ Kalmyk State University named after B.B. Gorodovikov, 358000, Pushkin Str., 11, Elista, Russia \\ ${ }^{2}$ State university of management, 109542, Ryazanskiy Ave., 99, Moscow, Russia
}

\begin{abstract}
This article is devoted to the disclosure of the essence and structure of the tourist complex as a specific type of socio-economic system at the regional level. The efficient and successful functioning of the economy of any territory as a single economic complex should be accompanied by the improvement of the organization of production structures and the rationalization of its sectoral composition. Thus, the improvement of the tourism sector occupies one of the most important places among a large set of interrelated issues in the development of the regional economy, which is due to the multiplier effect in the development of this industry. The authors analyzed the state, unique characteristics, level of potential and prospects of development of the tourism industry in order to identify the vector of social and economic growth of the region on the example of the Republic of Kalmykia.
\end{abstract}

\section{Introduction}

The tourism sector is a promising factor in the development of the economy of the Russian regions, which is understood not only as tourism activities in itself, but also in the whole range of related industries. Tourism, as a socio-economic phenomenon combines the market aspects of economic relations and socially oriented development goals of society.

\section{Materials and methods}

The purpose of the work is to assess the development of tourism in Russian regions.

The study analyzed statistical data published in open sources. In the work, scientific approaches and methods were used, among which statistical, logical, systemic, comparative, analytical and others, allowing to reveal the goal of the study.

\footnotetext{
* Corresponding author: uralan-danara@yandex.ru
} 


\section{Results}

Kalmykia is the land of steppes and deserts, a region with ancient history and culture, and unique flora and fauna. The Republic of Kalmykia is a beautiful and interesting area, it differs from most of the Russian cities and regions, which makes it even more interesting to travel. The Tourism in the Republic of Kalmykia brings economic benefits (performing its economic function), it has risen up the development of infrastructure, the hotel companies themselves, restaurants and trade organizations, and through taxation, such as visa fees, customs fees, and various indirect fees, which supplement the revenue structure of the budget.

Figure 1 shows the share of each type of tourism in the overall structure of tourism services in the Republic of Kalmykia.

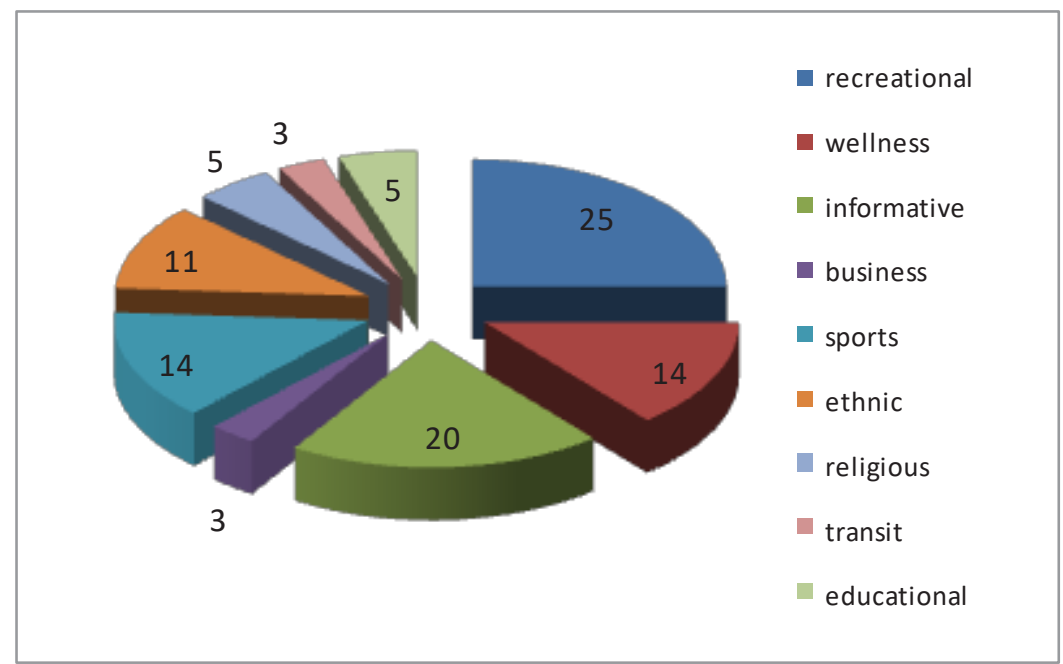

Fig. 1 Distribution of tourism types in the Republic of Kalmykia in 2019, \%

The Republic of Kalmykia has joined the TOP-10 the most promising regions for tourism. According to a survey conducted by the All-Russian Center for Public Opinion Research, $46 \%$ of Russian citizens would like to visit Kalmykia. The Republic of Kalmykia is on the seventh place in the ranking of regions of the country.

Thus, in the structure of tourism types in the Republic of Kalmykia, recreational, informative and wellness tourism occupies the greatest share. [8]

$10-12 \%$ per year is the increase in tourist flow in the Republic of Kalmykia. In 2019 the Republic, according to the generalized data, was visited by 418,000 tourists, tourist traffic in 2019 reached the value of one million. About $40 \%$ of the travellers come to familiarize themselves with the cultural heritage of the region.

The tourist flow of the Republic of Kalmykia can be conditionally divided into several categories:

- entertaining;

- excursion;

- business.

The first group includes Russians arriving in the region for the beach holidays. To the second - foreigners, as well as Russian tourist groups. The third category is represented both by entrepreneurs from Russia and the former CIS countries and from the European Union. [3] 
The modern type of tourism, which today is actively developing in Kalmykia, is a type of ethnocultural and event tourism. Event tourism is a recreation organization dedicated to all events or participation in spectacular events. In order to expand the activities of events, the Ministry of Tourism of Kalmykia is carrying out proactive work to maximize the number of events, increase the level of cultural events and intensify activities to modernize the repertoire of cultural organizations. One of the region's vibrant and popular events is the Festival of Tulips, The Lotus Festival, and the Jangariada Festival, which is the contemporary music festival of the peoples of Mongolia, national and religious holidays and many others. Such events promote the national cultural characteristics and traditions of the Republic of Kalmykia and attract new tourist flows to the Republic. The economic characteristic of ethnocultural tourism is the accumulation of assets, customs and national characteristics of ethnic culture, as well as the main goals and objectives of the socioeconomic development of the region and the improvement of competitiveness.

In order to assess the potential of ethnocultural resources, the following needs to be addressed:

- The analysis of the use of ethnocultural potential of the region;

- to assess the contribution of the potential of ethnocultural resources to enhancing the competitiveness of the region;

- the formation of basic prospects for studying the ethnocultural potential of the country and the region.[5]

Our region is recognized today as one of the most inexpensive territories for the spread of ethnocultural tourism. The richness and uniqueness of culture, historical sites, national customs and ethnic features of the Republic of Kalmykia form the foundation for the diversification of the tourism industry, which offers a wide range of services to Russian and foreign tourists. The development of the tourist direction of the republic has certain prospects for accelerating the development of the economy of the region. The Ministry of Culture of the Russian Federation has formed a concept for the development of the tourism sector in Russia until 2030. It consists of a number of measures, methods and tools of public policy that guarantee the achievement of public priorities.

It is officially recognized that tourism is one of the drivers of the growth of the regional economy of Kalmykia, which is confirmed by positive trends in the growth of the provision of tourist and excursion services. Thus, in 2014 the share of tourist and excursion services in the total volume of provided services was $12 \%$, and in 2018 this indicator reached $16 \%$. [7]

The development of the tourism industry allows not only to touch the origins of the history of an entire nation and its national culture, but also to study new traditions and cultures, which were previously unknown, and to expand the outlook of the ordinary urban resident. In addition, ethnoculture and event tourism is a form of cultural leisure for families and young generations interested in the history and traditions of their ancestors, whose brand is geographically unlimited, as it should interest Russian citizens and foreign tourists.

For the effective development of sectoral complexes by the Government of the Republic of Kalmykia within the framework of the Strategy of Social and Economic Development of the Republic of Kalmykia untill 2030 it is planned to form 4 regional clusters:

- agro-industrial;

- tourist;

- scientific and educational;

- medical services cluster. [2]

Thus, the Strategy for Social and Economic Development of the Republic of Kalmykia up to 2030 identifies as one of the strategic goals the formation of a unique integrated tourist product in the region, based on the national culture of the Kalmyk people, covering 
the directions of religious, cultural and cognitive, recreational, agrarian tourism, the creation of a modern tourist sector of the economy, which contributes to improving the quality of life of the population.

The favorable territorial location of the Republic, clean ecological environment, exotic landscapes, ethnic and cultural resources, recreational potential for the development of divided directions of tourism provide conditions for the development of a tourist cluster in the Republic of Kalmykia. [6]

The procedure of creating a tourist cluster in Kalmykia is closely related to the monitoring and formation of a publicly accessible information environment of these tourist facilities, the increase in the number of hotel rooms and collective means of accommodation of economy-level, meeting the current quality and safety standards, the improvement of habitat within settlements, the introduction of uniform standards of quality of service.

The tourist cluster in the region will become a unique core of attractiveness for domestic, foreign tourists, as well as for pilgrims, as it is the only subject professing Buddhism and acting as a kind of "brand" of the east in the European part of Russia.

In order to develop the tourist potential of the region within the framework of Strategy 2030 , it is proposed to create a tourist cluster "Journey to the Bumba Country" with the term of the project from 2020 to 2030 . The total cost of the project will be 3049.50 million rubles.

Within the framework of the strategic geographical framework of the cluster, it is planned to determine the priority territories of the Republic for the development of tourism:

- Lagan, in connection with the future construction of the port;

- Tsagan Aman with access to The Volga River;

- Yashaltinsky district with the presence of the therapeutic lake Solenoe;

- Elista as the capital of the republic.

\section{Discussions}

The tourist cluster will include:

- multifunctional tourist complexes in the Kalmyk style, including mini-hotels, national cuisine, recreation and entertainment infrastructure, sports sections, shopping areas, livestock parking, extreme facilities. Such complexes would be located along highways to achieve high cross-country capacity;

- health complexes: health center of eastern medicine "Manla," the center of hippotherapy "Contour Club," in Elista, health zone on tha Lake Solenoe in Yashaltin district, koumiss hospital in Lola village;

- tourist recreation areas, including collective facilities for accommodation in minihotels, cafes, a bath, a recreation center and a relax, a sports complex: the "Sea Profit" turbase in Lagan, the Volga River turbase in Tsagan Aman village, an object based on the Saigachonok children 's camp "in the Celina district;

- leisure facilities: a pilgrimage center in Arshan village near the Buddhist temple "Syakyusn Syum," on the territory of which it is planned to build a CMP (collective means of placement) in the form of a hotel for 130 seats, a meditation center, a yoga studio, a workshop of art crafts and painting, an administrative building, a recreation area. 


\section{Conclusion}

The implementation of measures to create a tourist and recreational cluster of the Republic of Kalmykia in accordance with the ideology of the cluster strategy of the Russian Federation will allow [4]:

- increase the non-price competitiveness of tourism;

- to increase the export of tourism products;

- stimulate the growth of the number of small and medium-sized business entities in the tourism industry;

- create conditions for rapid innovation in tourism;

- ensure the success of the tourism training programme;

- increase the investment attractiveness of the tourism industry of the region for potential foreign and Russian investors;

- contribute to the social and economic development of the territory of the tourism and recreation cluster as a whole.

\section{References}

1. State Program of the Republic of Kalmykia «Development of Culture and Tourism of the Republic of Kalmykia for 2019-2025»

2. Strategy of social and economic development of the Republic of Kalmykia till 2030.

3. M. V. Vinogradova, Development of tourism in the region: financial aspect, Service in Russia and abroad, 5, 110-126 (2019)

4. V. Y. Karakova, Bulletin of Science and Practice, 4 (7), 329-335 (2018)

5. Problems of Tourism Development: Scientific and Practical Journal, 1 S, 67-68 (2014)

6. D. B. Erendzhenova, A. B. Badmayeva, A. A. Manjieva, A. L. Darmayev, Ch. S. Alykov, V. I. Baskhayeva, Journal of the Altay Academy of Economics and Law, 1, 133-137 (2020)

7. The official website of the Office of the Federal Service of State Statistics for the Astrakhan Region and the Republic of Kalmykia

8. Recreation and tourism in Kalmykia, URL http://www.wisetravel.ru/russia/kalmykiia/otzyv-141.html 